\author{
S.V. Solodyankina, Yu.V. Vanteeva
}

V.B. Sochava Institute of Geography SB RAS, Irkutsk, Russia

Corresponding author: solodyankinasv@mail.ru

\title{
Geosystems of the Primorsky ridge (Baikal region) — classification and mapping
}

\begin{abstract}
In this article, the application of landscape approach for geosystem classification and mapping was discussed on the example of the landscapes of the Primorsky ridge (Baikal region). Authors of this study used the geosystem concept formulated by V. Sochava and method of factorial-dynamical series of facies developed by A. Krauklis for modeling landscape structure of study area. The basis for the development of a hierarchical classification of geosystems was the data of fieldwork at 70 plots. The ordination of the plots by three parameters (topographic wetness index, slope steepness and humus thickness) was carried out using the method of ternary plots to group geosystems into classes and determine their dynamic state. The landscape map was compiled at the local scale $(1: 50000)$ based on fieldwork, DEM, and remote sensing data. As a result, 14 groups of facies were identified in the study area. They were represented by both climax and succession stages, as well as anthropogenic modifications. The main classes of facies formed under the influence of local environmental factors were revealed using factor-dynamic analysis. They are represented by the following dynamic series: sublithomorphic, subhydromorphic, and subxerolithomorphic. The $66 \%$ of the study area is occupied by landscapes of the sublitomorphic series.
\end{abstract}

Keywords: factoral-dynamical series of facies, landscape approach, geosystem structure, hierarchical classification, landscape typological map, satellite images, digital elevation model, ordination.

\section{Introduction}

The optimal and sustainable land use is achieved on the basis of understanding the processes occurring in the natural system. The classification of geosystems and their mapping is one of the main methods for studying the spatial structure of landscapes. Despite the active development of geo-information technologies, remote sensing methods and improvement of computer processing of spatial data, which greatly facilitates the work, to date, a unified approach to the compilation of landscape maps has not been developed. This circumstance is inextricably linked with the absence of a generally accepted taxonomic system of landscape units, which is due to the issues of landscape modeling that are still unresolved in the theory of landscape science (reflection of emergent properties, geostationary and geodynamic essence of the landscape, determination of hierarchical levels of landscape organization) [1].

Various approaches are used to identify the structural units of landscapes. One of such approaches is the theory of geosystems [2]. The geosystem approach is widely used in the applied aspects of landscape science, landscape ecology, and landscape planning [3-6].

The study of the landscape structure using various models allows to get a more complete picture of the processes of integration and differentiation in the geographic envelope [7].

Typification and classification of geosystems are aimed at identifying the general properties of geosystems and their invariants for different locations (conditions) [8]. In most cases, the typification of landscapes is based on morphological and functional indicators [9].

The aim of the study is to compile a hierarchical classification of the geosystems of the Primorsky Ridge in the Baikal region and to carry out large-scale mapping of a test site of this territory.

Landscapes of the Primorsky Ridge (Baikal region) were selected as the object of research. The study area with an area of $283.4 \mathrm{~km}^{2}$ shown in Figure 1 is located in the southern part of the ridge, within the central ecological zone of the Baikal natural territory which is insufficiently studied in terms of landscape [10]. The relief of the territory is low-mountainous $(460-1177 \mathrm{~m}$ ), characterized by deep dissection (up to $600 \mathrm{~m}$ ) and significant steepness of slopes (up to $60^{\circ}$ ). The annual arrival of total solar radiation is 4400 $4600 \mathrm{~mJ} / \mathrm{m}^{2}$ [11]. The climate is humid with moderately cold summers and winters. The annual amount of precipitation on the windward (northwestern) slopes and crests of the ridge is 400-600 mm, on the leeward (facing Baikal) - 200-300 mm [12]. The thickness of the snow cover reaches $60 \mathrm{~cm} \mathrm{[11].}$ 


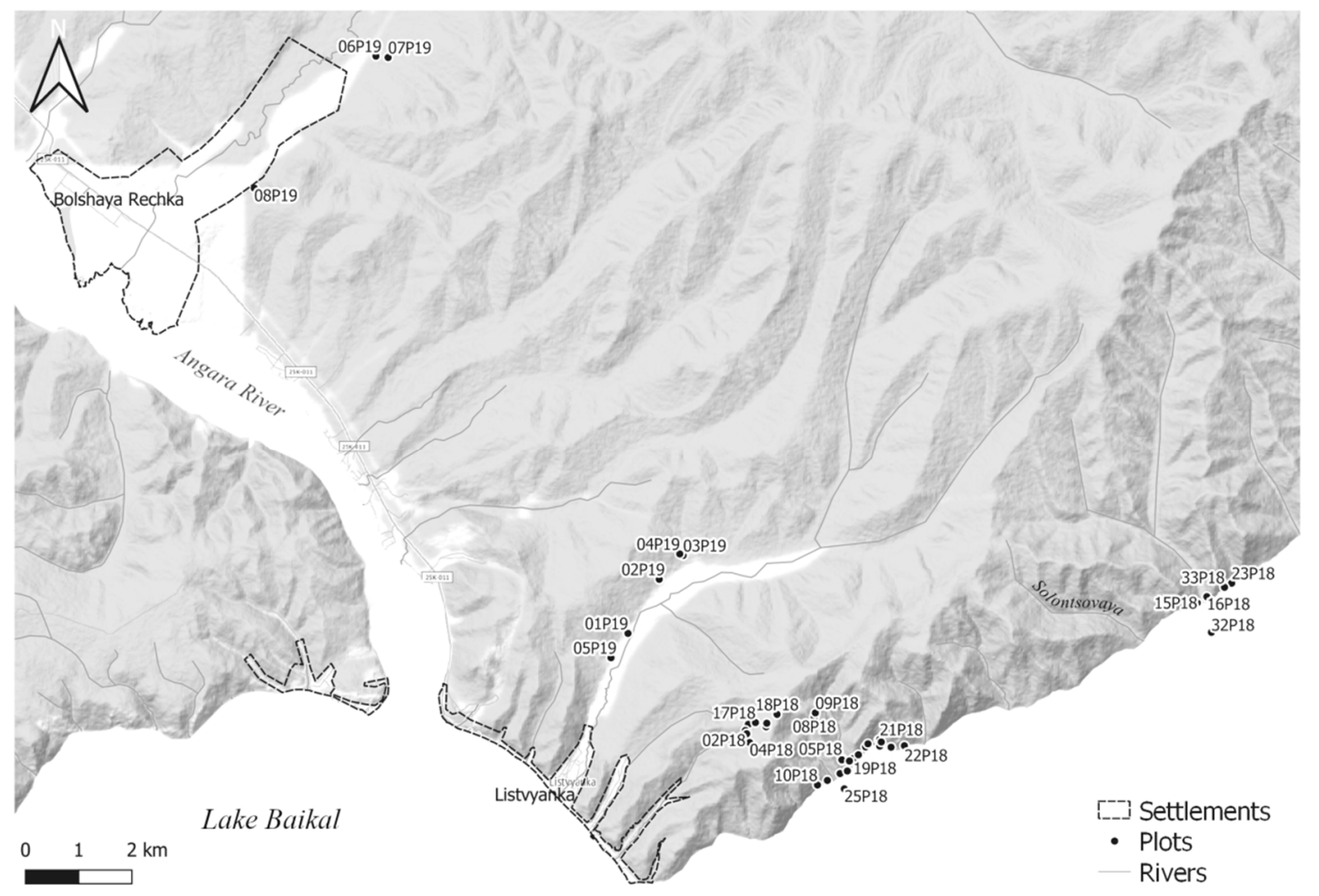

Figure 1. The location of the study area and test plots (the background is "Stamen Terrain" http://maps.stamen.com/)

Mountain-taiga light-coniferous forests are widespread in the territory. The watersheds and nearwatershed parts of the slopes are dominated by mountain-taiga dark coniferous, mainly cedar forests with the participation of fir, larch, and pine. Warmed by the sun, the slopes of the southern and southeastern exposure are occupied mainly by steppe larch and pine forests in combination with steppes. The valley bottoms are covered with meadows and swamps. Various stages of restorative successions are also common in the study area - young and middle-aged birch-aspen, aspen-birch, and larch-pine forests [13].

\section{Experimental}

The research included several stages: collecting information about the study areas (thematic maps, space images, etc.); field works (geographical and botanical descriptions of sample plots); the creation of GIS-projects and databases; classifications of geosystems using geosystem approach; delineation of the borders of landscape units using methods of GIS analysis and processing of remote sensing data; computerbased supervised classification of landscape units [14].

The input data were digital elevation models (SRTM with a resolution of $30 \mathrm{~m}$ ), topographic maps $(1: 200,000)$, multispectral space images (Landsat-8 with a resolution of $30 \mathrm{~m}$ ), the map of landscapes of the South of Eastern Siberia $(1: 1,500,000)[15]$, geological maps $(1: 200,000)$ and other published thematic maps (landcover, land use, vegetation and soil units), literature data.

The main sources of information about the studied landscapes were field data. Between 2017 and 2020, 70 physical-geographical descriptions (look it on https://www.researchgate.net/publication/337944189 Primorskij_hrebet) were completed on the study areas. Representative sample plots (15 to $15 \mathrm{~m})$ characterizing the landscape diversity was laid in all major landforms.

At the stage of preliminary landscape mapping, an automatic classification of images from different seasons was carried out using the ISODATA method, then by using a digital elevation model, a classification of relief forms based on the index of the topographic position was conducted. According to the combination of classification parameters for the image and the relief form, each section is assigned to a certain type of landscape by the preliminary classification of geosystems [13]. As a result, we concluded that the use of remote sensing and GIS data is still impossible without carrying out field studies and manual correction of the contours and their parameters. The high fragmentation of the landscape contours obtained by this method $(104,000)$ required generalization and editing based on the data of field complex studies and other above- 
mentioned spatial data collected in the working project. In the range of scales 1:5,000 to 1:25,000, the contours were re-digitized using the QGIS program (their number was reduced by more than a hundred times). Work with spatial data was carried out in the geographic coordinate system WGS-84, in the universal transverse Mercator projection (UTM), zone $48 \mathrm{~N}$.

The legend to the map was improved: the facies groups were ordered according to the facies classes depending on their belonging to a certain factor-dynamic series [16], in which the root variant, which is closest to the zonal norm (or altitudinal belt), and serial facies groups, modified under the influence of a certain factor (lithomorphic, hydromorphic, cryomorphic, etc.) or a set of factors. The degree of influence of landscape-forming factors was determined from the data obtained during the processing of the DEM (landform, slopes, exposure of slopes, topographic moisture index), and from data on the type of vegetation [17].

Classification of geosystems was carried out for a number of geomers: examples of facies (the lowest hierarchical level), groups of facies, classes of facies, and geoms (highest hierarchical unit at the local level). To determine the factoral-dynamic series of facies and groups of facies, we performed ordination of test plots along the axes of three parameters as follows: the thickness of the humus horizon (field data), the topographic moisture index, and the slope calculated from DEM. The identified groups of sample plots were provided with the characteristics of the microrelief, vegetation, and soils. After that, they were ordered into typological units (groups of facies) [18].

Geoms were identified from their belonging to a particular belt, with similar structural characteristics of soil cover and vegetation. The class of facies is defined as the set of facies of one factorial-dynamical series and has its own primary variant (the primary group of facies), which are closest to the zonal norm, and serial groups of facies which are modified by a particular leading factor. In this case, the facies are connected by one equifinal state with a corresponding primary plant formation. Groups of facies are identified according to the degree of seriality (variability, reduction) and, hence, a decrease of the degree of correspondence to the zonal norm. They are separated according to the degree of modification into the following categories: primary $(\mathrm{P})$ - facies in which the series of successions end with the establishment of a relative stability of biogeocenoses; pseudo-primary (PP) - facies characterized by the hypertrophied influence of one or several environmental factors which endows the biogeocenoses with a significant potential dynamism, additionally, serial (S) - facies where no stabilization of the structure and regimes of the biogeocenoses is reached because of the environmental conditions [17].

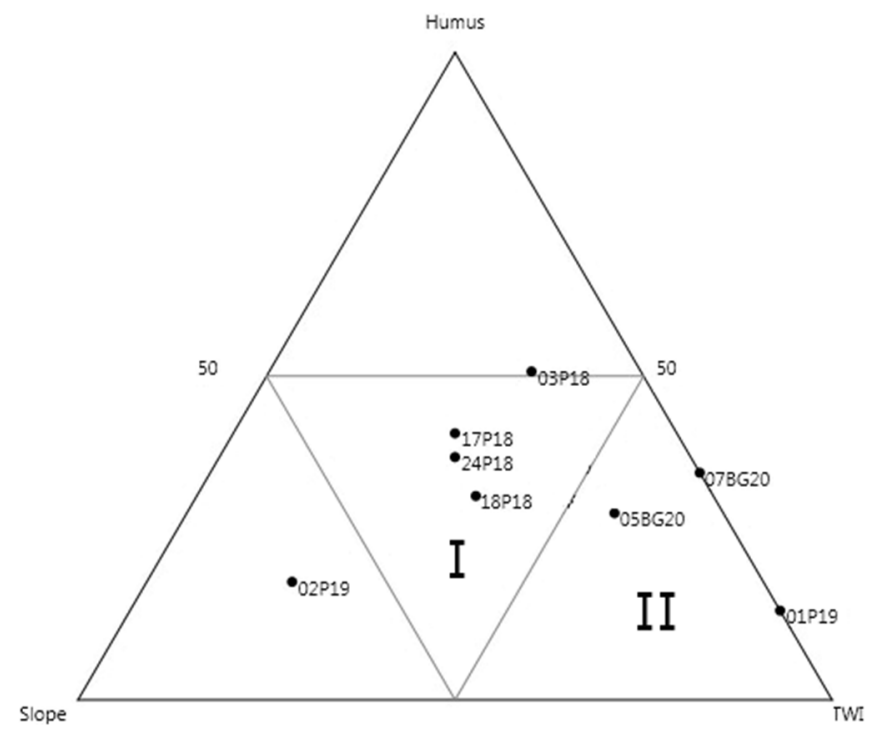

Figure 2. Ordination of plots belonging to two geomes: Mountain dark coniferous taiga and Cedar-larche taiga of intermountain basins and valleys (I - the facies close to the primary dynamic state, II — the facies close to the pseudo-primary state of subhydromorphic series) in the space of indicators of three factors: the thickness of the humus horizon, the topographic moisture index, the steepness of the slope

The ordination of the descriptions was carried out by constructing a ternary plot (Fig. 2). When constructing it, a triangular coordinate system on a plane is used to study the relationships between three 
variables. As a result, the main factor series were identified - sublitomorphic (structural-denudation surfaces characterized by significant substrate skeletal structure), subhydromorphic (drainage depressions, valleys, and valleys, characterized by increased moisture) and subxerolithomorphic, formed under the influence of a complex of factors: arid conditions characteristic of slopes, in the rain shade, and the skeletal nature of the substrate. Classes of facies are grouped into geomes according to the zonal affiliation and similar structural features of the vegetation cover. The hierarchical levels above the geome are given following the legend of the map "Landscapes of the South of Eastern Siberia" [15].

As the result of landscape classification, the 5 geoms, 7 classes of facies and 14 groups of facies were identified on the study area (Tab. 1, Fig. 3). The calculation of the areas showed that the larch-pine forest with the admixture of aspen and rhododendron, red bilberry, small grasses, and often with Bergenia and green mosses on steep slopes (group of facies № 6, see Table 1 and Fig. 3) is most widespread in the study area. It covers $19 \%$ of the territory. The group of facies № 2 (see Tab. 1 and Fig. 3) also occupies a large area $(17 \%)$.

\section{Results and Discussion}

Secondary mixed aspen-birch and birch-aspen forb grass forests (№ 4a, 7a, 9a) cover $5.7 \%$ of the study area. Anthropogenically transformed landscapes occupy an insignificant area (3.4\%) and are represented mainly by several small villages.

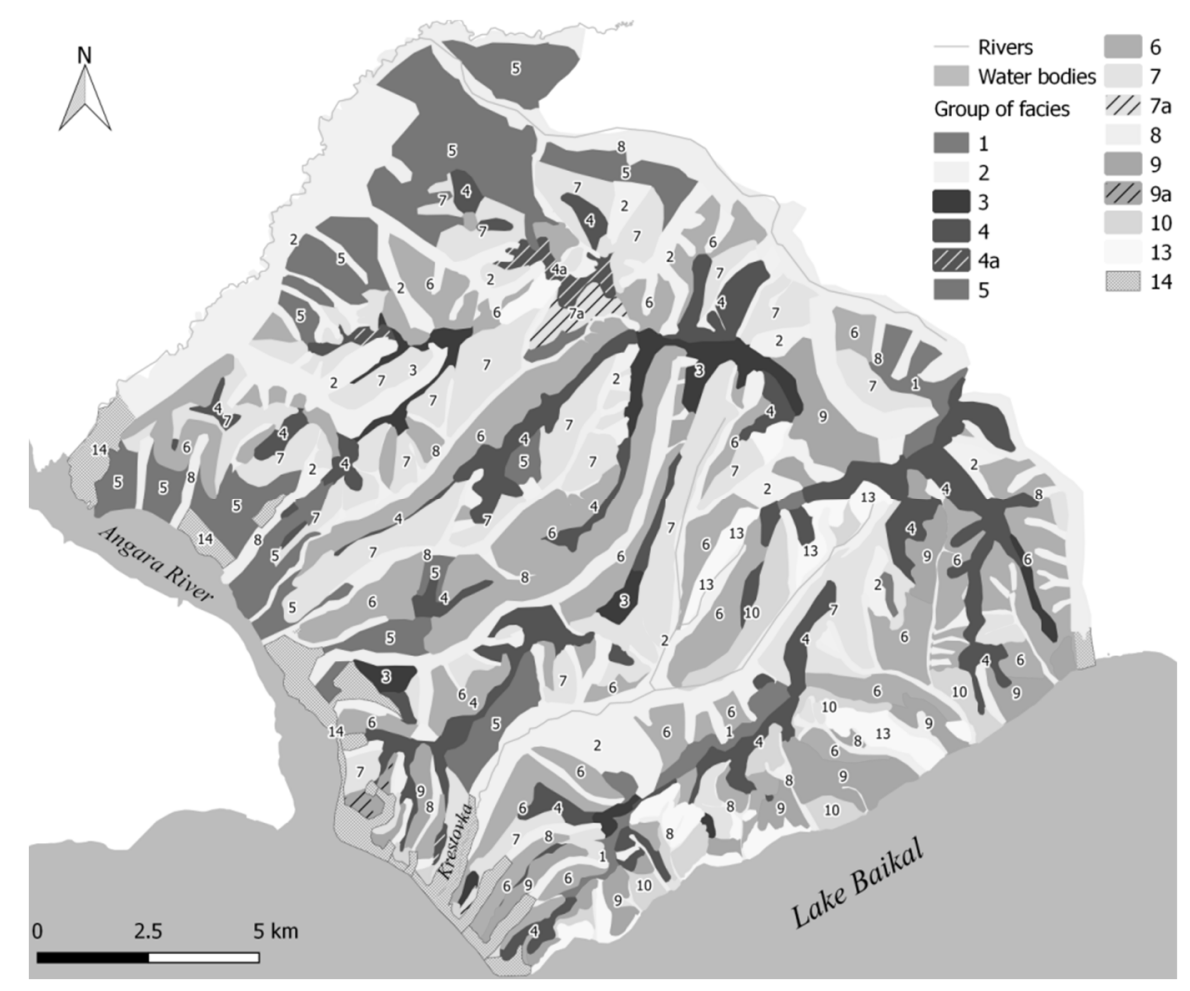

Figure 3. Geosystems of the southern part of the Primorsky ridge

The fragment of legend to the map "Geosystems of the southern part of the Primorsky ridge"

\begin{tabular}{|c|c|c|}
\hline № & Group of facies & \\
\hline \multicolumn{2}{|c|}{ Class of geoms "Mountain taiga of South Siberia” } & $\begin{array}{l}\text { Dynamic state } \\
\text { of geosystem* }\end{array}$ \\
\hline \multicolumn{2}{|c|}{ Geom "Mountain dark coniferous taiga” } \\
\hline \multicolumn{2}{|c|}{ Class of sublithomorphic facies } \\
\hline \multirow{2}{*}{1} & $\begin{array}{l}\text { Fir (Abies sibirica Ledeb.) - Siberian cedar (Pinus sibirica Du Tour) forest with shrubs } \\
\text { (Duschekia fruticose (Rupr.) Pouzar, Sorbus sibirica Hedl.) and Bergenia (Bergenia crassifolia } \\
\text { (L.) Fritsch) on narrow watersheds and near-watershed slopes (03P18, 17P18, 18P18, 24P18)** }\end{array}$ & P \\
\hline
\end{tabular}




\begin{tabular}{|c|c|c|}
\hline \multicolumn{2}{|r|}{ 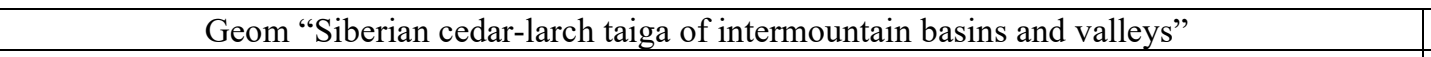 } & \multirow[b]{3}{*}{$\mathrm{PP}$} \\
\hline \multicolumn{2}{|r|}{ Class of subhydromorphic facies } & \\
\hline 2 & $\begin{array}{l}\text { Siberian cedar-larch (Larix sibirica Ledeb.) with the admixture of spruce (Picea obovate } \\
\text { Ledeb.) and birch (Betula spp.) shrubby (Rhododendron dauricum L., Spiraea media Schmidt) } \\
\text { forest with red bilberry (Vaccinium vitis-idaea L.), small grasses (Lycopodium annotinum L., } \\
\text { Maianthemum bifolium (L.) F.W. Schmidt) and green mosses (Pleurozium schreberi (Brid.) } \\
\text { Mitt.) (02P19, 05P19, 05BG20) combined with birch - spruce shrubby (Duschekia fruticosa, } \\
\text { Chamaedaphne calyculata (L.) Moench) forest with sedge and sphagnum in intermountain } \\
\text { basins and valleys (01P19,07BG20) }\end{array}$ & \\
\hline \multicolumn{2}{|r|}{ Geom "Mountain light coniferous taiga" } & \\
\hline \multicolumn{2}{|r|}{ Class of sublithomorphic facies } & \\
\hline 3 & $\begin{array}{l}\text { Larch-pine (Pinus sylvestris L.) with Siberian cedar undergrowth and rhododendron } \\
\text { (Rhododendron dauricum) suffruticose (Linnaea borealis L., Vaccinium vitis-idaea) forest with } \\
\text { green mosses on watersheds and near-watershed slopes (03BG20, 03БГ18) }\end{array}$ & $\mathrm{P}$ \\
\hline 4 & $\begin{array}{l}\text { Pine forest with larch, forb (Chrysanthemum zawadskii Herbich), and legume grasses (Lathyrus } \\
\text { humilis (Ser.) Spreng., Vicia cracca L.) on watersheds and near-watershed slopes with rocks } \\
(01 \mathrm{BG} 18)\end{array}$ & $\mathrm{S}$ \\
\hline $4 \mathrm{a}$ & $\begin{array}{l}\text { Secondary mixed aspen (Populus tremula L.) — birch (Betula spp.) and birch-aspen forb grass } \\
\text { forests }\end{array}$ & \\
\hline 5 & $\begin{array}{l}\text { Larch-pine shrubby (Ledum palustre L., Rhododendron dauricum, Duschekia fruticosa) forest } \\
\text { with Siberian pine undergrowth, red bilberry and small grasses (Maianthemum bifolium, } \\
\text { Linnaea borealis) combined with sedge (Carex sabynensis Less. ex Kunth) and green mosses } \\
\text { (Pleurozium schreberi, Polytrichum commune Hedw.) on gentle slopes and piedmont plains } \\
(03 \mathrm{P} 19,04 \mathrm{P} 19,06 \mathrm{P} 19,07 \mathrm{P} 19)\end{array}$ & $\mathrm{PP}$ \\
\hline 6 & $\begin{array}{l}\text { Larch-pine with the admixture of aspen forest with rhododendron (Rhododendron dauricum), } \\
\text { red bilberry, small grasses, and often with Bergenia and green mosses on steep slopes (08P18, } \\
\text { 08P19, 09P18, 03БГ17, 04БГ20) }\end{array}$ & $\mathrm{S}$ \\
\hline 7 & $\begin{array}{l}\text { Larch-pine with the admixture of aspen and birch forest with small grasses (Maianthemum } \\
\text { bifolium Galium boreale L.), legume grasses (Vicia baicalensis (Turcz.) B. Fedtsch., Vicia } \\
\begin{array}{l}\text { amoena Fisch.), and graminoids (Calamagrostis arundinacea (L.) Roth, } \\
\text { Brachypodium pinnatum (L.) Beauv.) mostly on steep slopes (01P18, 02P18, 04P18, 11P18) }\end{array}\end{array}$ & $\mathrm{S}$ \\
\hline \multirow{2}{*}{\multicolumn{2}{|c|}{ Secondary mixed aspen-birch and birch-aspen forb grass forests }} & \\
\hline & & \\
\hline 8 & $\begin{array}{l}\text { Birch-larch with Siberian cedar and pine shrubby (Rosa acicularis Lindl., Spiraea spp.) forest } \\
\text { with sedge (Carex macroura Meinsh.) and forb grasses (Allium microdictyon Prokh., Rubus } \\
\text { saxatilis L.) (05P18, 02BG20, 01BG20), sometimes replaced by small grasses (Trientalis } \\
\text { europaea L., Maianthemum bifolium) and shavegrass (Equisetum spp.) (16P18) combine with } \\
\text { shrubby (Padus avium Mill., Spiraea flexuosa Fisch. ex Cambess.) meadows with tall grasses } \\
\text { (Cardamine macrophylla Willd., Aconitum septentrionale Koelle) and fern (Matteuccia } \\
\text { struthiopteris (L.) Tod.) in valleys (06P18,07P18) }\end{array}$ & $\mathrm{S}$ \\
\hline \multicolumn{2}{|r|}{ Geom «Piedmont light-coniferous subtaiga» } & \\
\hline \multicolumn{2}{|r|}{ Class of sublithomorphic facies } & \\
\hline 9 & $\begin{array}{l}\text { Larch-pine shrubby (Spiraea media, Rhododendron dauricum, Rosa acicularis) forest with } \\
\text { legume grasses (Vicia unijuga A. Braun, Vicia nervata Sipliv., Lathyrus humilis) and } \\
\text { graminoids (Calamagrostis arundinacea, Poa sergievskajae Prob) often with forb (Pulsatilla } \\
\text { patens (L.) Mill., Iris ruthenica Ker Gawl., Chrysanthemum zawadskii Herbich) on steep slopes, } \\
\text { mainly of southern and southeastern aspect (19P18, 20P18, 21P18, 22P18, 26P18, 27P18, } \\
\text { 29P18, 30P18, 31P18, 06BG20,04BG18) }\end{array}$ & S \\
\hline $9 \mathrm{a}$ & Secondary mixed aspen-birch and birch-aspen forb grass forests & \\
\hline \multicolumn{2}{|r|}{ Class of subxerolithomorphic facies } & \\
\hline 10 & $\begin{array}{l}\text { Steppificated pine forest with cotoneaster (Cotoneaster melanocarpus Fisch. ex Blytt, } \\
\text { Cotoneaster lucidus Schltdl.), sedge (Carex korshinskyi Kom.), graminoids (Koeleria cristata } \\
\text { (L.) Pers., Agropyron distichum (Georgi) Peschkova), and forb (Rhaponticum uniflorum (L.) } \\
\text { DC., Kitagawia baicalensis (I. Redowsky ex Willd.) Pimenov, Artemisia gmelinii Weber ex } \\
\text { Stechm.) on steep slopes, mainly of southern aspect (10P18, 13P18, 01BG17, 02BG18, 23P18, } \\
\text { 33P18) }\end{array}$ & $\mathrm{S}$ \\
\hline
\end{tabular}


Geosystems of the Primorsky ridge (Baikal region) ...

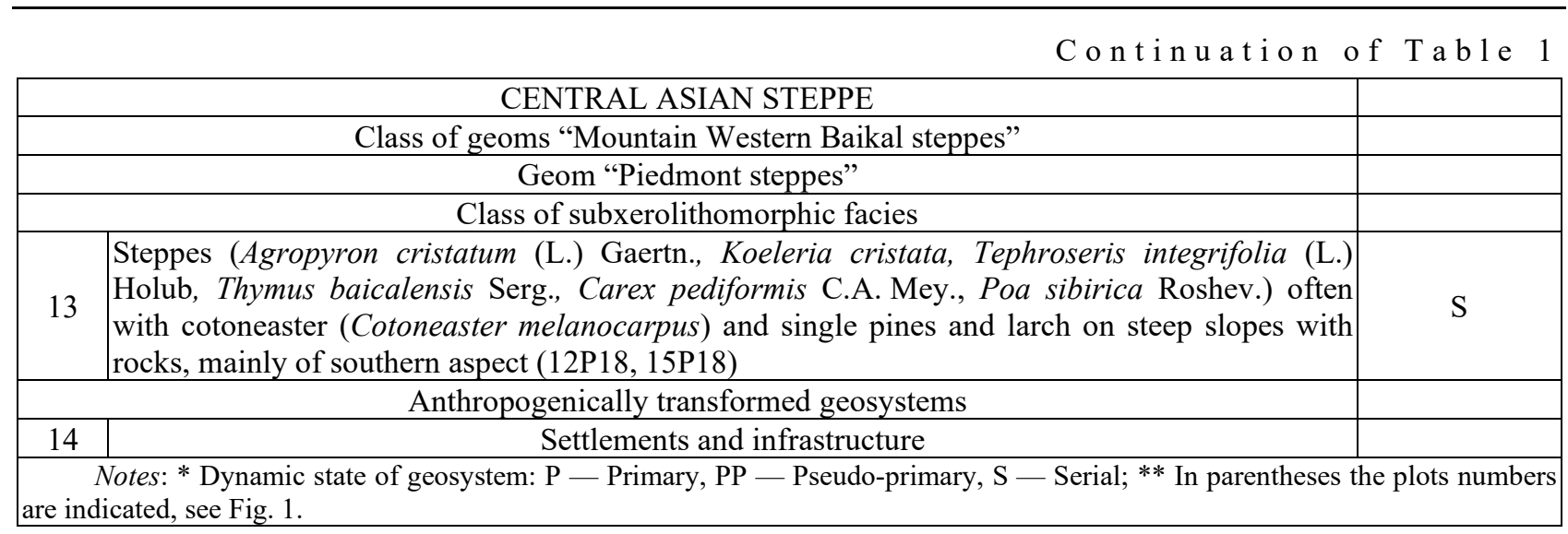

As noted by D.V. Zolotov and D.V. Chernykh [19], in addition to constructing factorial-time series, other principles of systematization of geosystems at the topological level have been developed, for example, the classification of elementary landscape areas by L.G. Ramenskiy, geochemical classification of elementary landscapes, universal typological classification of facies by Prokaev et al. [20], etc. However, it is the factorial-dynamic approach of A.A. Krauklis "takes into account the lateral connections that go beyond the gravity conjugation of locations and, despite the functional-dynamic basis, makes it possible to judge the genesis of the landscape structure" [16]. The resulting model of factorial-dynamic series, built-in with a hierarchical classification, links local data with the region as a whole and makes it possible to trace the dynamics of geosystems, taking into account their genesis. This approach allows to identify the relationships between geosystems, which are considered as stable systems but subject to continuous changes under the influence of various factors. In this case, the structure is understood as an invariant (unchanging) aspect of the system, and the dynamics are a rhythmic change in the states of the geosystem under the influence of internal and external factors within a certain time interval, which does not lead to a change in its structure [21]. Field landscape mapping, despite the development of remote sensing methods, remains relevant. Without these soil descriptions, it is difficult to accurately determine the root state of areas of the territory that are in the stages of restorative succession.

\section{Conclusions}

The main features of the landscape structure of the southern part of the Primorsky Ridge are identified based on the analysis of the results of geosystem classification and mapping. Geosystems of the study area are represented by a combination of four types of mountain taiga geoms (correlated with high-altitude zones) and one steppe geom. Such a contrast in a relatively small area is due to the influence of the barrier effect under conditions of high-altitude zonation. Steppe landscapes are formed on the slopes of the southern and southeastern exposure in conditions of a rain shadow.

The seven classes of facies formed under the influence of local environmental factors are represented by the following dynamic series: sublithomorphic, subhydromorphic, and subxerolithomorphic. Factoraldynamic analysis of the geosystems showed that deep ruggedness of the relief and significant distribution of steep slopes have the greatest impact on the formation of geosystems at the local level. The study area is mostly occupied by landscapes of the sublitomorphic series (66\%) also $29 \%$ of the territory is covered with landscapes of the subhydromorphic series, and $5 \%$ - subxerolithomorphic. Only $5 \%$ of the study area is occupied by landscapes in a primary dynamic state.

The modeling landscape structure in the framework of the geosystem approach using factoraldynamical series of groups of facies allows considering both regional and local factors of landscape forming. This can be of great practical importance for predict changes in the landscape structure under the influence of both natural and anthropogenic factors, ecological monitoring, assessing the resource potential of the territory and landscape functions, landscape planning, and other applied tasks.

\section{Acknowledgment}

This study was performed within the framework of state assignment (registration No. AAAA-A21121012190056-4). 


\section{References}

1 Колбовский Е.Ю. ГИС-моделирование и проблемы теории ландшафта / Е.Ю. Колбовский // Современное ландшафтно-экологическое состояние и проблемы оптимизации природной среды регионов: материалы ХІІІ Междунар. ландшафт. конф.: В 2-х т. - Т. 1 / под ред. В. Б. Михно. - Воронеж: Истоки, 2018. - С. 31-34.

2 Сочава В.Б. Введение в учение о геосистемах / В.Б. Сочава. - Новосибирск: Наука, 1978. — 319 с.

3 Bastian O. Landscape services: The concept and its practical relevance / O. Bastian, K. Grunewald, R.-U. Syrbe et al. // Landscape Ecology. — 2014. - Vol. 29 (9). - P. 1463-147.

4 Bastian O. The significance of geosystem and landscape concepts for the assessment of ecosystem services: Exemplified in a case study in Russia Landscape Ecology / O. Bastian, K. Grunewald, A.V. Khoroshev // Landscape Ecology. — 2015. — Vol. 30 (7). - P. 1145-1164.

5 Semenov Yu.M. Landscape-Geographical Support of the Ecological Policy of Nature Management in Regions of Siberia / Yu.M. Semenov // Geography and natural Resources. - 2014. - Vol. 35, No. 3. - P. 208-212.

6 Khoroshev A.V. Landscape Patterns in a Range of Spatio-Temporal Scales /A.V. Khoroshev K.N. Dyakonov // Landscape Series. — 2020. — Vol. 26. — Springer, Cham. — P. 446. https://doi.org/10.1007/978-3-030-31185-8_8

7 Черных Д.В. Пространственная организация ландшафтов бассейна реки Барнаулки / Д.В. Черных, Д.В. Золотов; отв. ред. И.Н. Ротанова; РАН, Сиб. отд.; Ин-т вод. и экол. проблем. - Новосибирск: Изд-во СО РАН, 2011. — 205 с.

8 Cherkashin A.K. Polygeosystem Fundamentals of Landscape Science / Khoroshev A., Dyakonov K. (Eds.) // Landscape Patterns in a Range of Spatio-Temporal Scales. Landscape Series. - 2020. — Vol. 26. - P. 19-40. https://doi.org/10.1007/978-3-030-31185-8_8

9 Коновалова Т.И. Ландшафтно-интерпретационное картографирование / Т.И. Коновалова, Е.П. Бессолицына, И.Н. Владимиров и др. - Новосибирск: Наука, 2005. — 424 с.

10 Истомина Е.А. Итоги ландшафтно-картографических исследований в Прибайкалье / Е.А. Истомина, С.В. Солодянкина, Ю.В. Вантеева, Т.И. Коновалова, А.Ю. Бибаева, А.А. Фролов, М.В. Цыганкова // Геодезия и картография. - 2018. - Т. 79, № 2. — С. 36-47. https://doi.org/10.22389/0016-7126-2018-932-2-00-00

11 Атлас. Байкал / ред. Г.И. Галазий. - М.: Изд-во Федеральной службы геодезии и картографии России, 1993. $160 \mathrm{c}$.

12 Трофимова И.Е. Типизация и картографирование климатов Байкальской горно-котловинной системы / И.Е. Трофимова // География и природные ресурсы. — 2002. — № 2. — С. 53-61.

13 Вантеева Ю.В. Геоинформационное картографирование ландшафтов на примере Приморского хребта (Прибайкалье) / Ю.В. Вантеева, Е.А. Распутина, С.В. Солодянкина // Геодезия и картография. — 2019. — Т. 80, № 12. - С. $20-30$. https://doi.org/10.22389/0016-7126-2019-954-12-20-30

14 Vanteeva J.V. Application of geosystem approach for landscape function assessment at the local level / J.V. Vanteeva, S.V. Solodyankina // New trends in geography: Proceedings of International Scientific Symposium. (October 3-4, 2019, Ohrid, Republic of North Macedonia). — Skopje: Macedonian Geographical Society, 2019. — P. 15-25.

15 Ландшафты юга Восточной Сибири [Карты]: [физическая карта] / Авт. В.С. Михеев, В.А. Ряшин, 1:1 500 000. — М.: ГУГК, 1977. — 4 л.

16 Крауклис А.А. Проблемы экспериментального ландшафтоведения / А.А. Крауклис. — Новосибирск: Наука, 1979. $232 \mathrm{c}$.

17 Solodyankina S.V. Classification and mapping of topogeosystems by the method of factorial-dynamical series of facies / S.V. Solodyankina, Yu.V. Vanteeva, A.A. Cherkashina, V.V. Chepinoga // Geography and Natural Resources. — 2018. — Vol. 39, № 3. - P. 261-269. https://doi.org/10.1134/S1875372818030101

18 Vanteeva Y.V., Solodyankina S.V. Structure and Phytomass Production of Coastal Geosystems Near Lake Baikal / Y.V. Vanteeva, S.V. Solodyankina // Khoroshev A., Dyakonov K. (Eds.) Landscape Patterns in a Range of Spatio-Temporal Scales. — Landscape Series. — 2020. — Vol. 26. — P. 121-137. https://doi.org/10.1007/978-3-030-31185-8_8

19 Золотов Д.В. Фациальная организация высокогорий северного макросклона хребта Холзун (Русский Алтай) / Д.В. Золотов, Д.В. Черных // География и природные ресурсы. — 2017. — № 4. — С. 83-93.

20 Прокаев В.И. Типы фаций - единицы детального ландшафтного картографирования / В.И. Прокаев // Изв. ВГО. 1983. - Т. 115, Вып. 6. - С. 432-441.

21 Сочава В.Б. Проблемы физической географии и геоботаники. Избр. тр. / В.Б. Сочава. — Новосибирск: Наука, 1986. $-344 \mathrm{c}$. 


\title{
С.В. Солодянкина, Ю.В. Вантеева \\ Приморск жотасының геожүйелері (Байкал аймағы) Жіктеу және картаға түсіру
}

\begin{abstract}
Мақалада Приморск жотасының (Байкал аймағы) ландшафттары мысалында геожүйелерді жіктеу және картаға түсіру үшін ландшафт тәсілін қолдану қарастырылған. Ауданның ландшафттық құрылымының моделін зерттеу үшін В. Сочава құрастырған геожүйе тұжырымдамасы және А. Крауклис әзірлеген фациялардың факторлық-динамикалық қатарлар әдісі қолданылған. Геожүйелердің иерархиялық классификациясын әзірлеуге 70 учаскедегі дала жұмыстарының деректері негіз болды. Графиктерді үш параметр бойынша үйлестіру (топографиялық ылғалдылық индексі, еңіс тіктігі және қарашіріктің қалыңдығы) геожүйелерді сыныптар бойынша топтастыру және олардың динамикалық жай-күйін анықтау үшін үшбірлік графиктер әдісімен жүргізілді. Ландшафттық карта далалық жұмыстар, DEM және қашықтықтан зондтау деректері негізінде жергілікті машстабта (1:50 000) құрастырылды. Нәтижесінде зерттелетін аймақта фациялардың 14 тобы анықталды. Олар шарықтау шегі мен сабақтастық кезеңдерімен де, антропогендік модификациялармен де ұсынылған. Жергілікті қоршаған орта факторларының әсерінен пайда болатын фациялардың негізгі кластары факторлық-динамикалық талдау көмегімен анықталады. Олар мына динамикалық қатарлармен ұсынылған: сублитоморфты, субгидроморфты және субсеролитоморфты. Зерттеу алаңының 66 \% ын сублитоморфты қатардың ландшафттары алып жатыр.
\end{abstract}

Кілm сөздер: фациялардың факторлық-динамикалық қатары, ландшафтық тәсіл, геожүйенің құрылымы, иерархиялық жіктеу, ландшафттық типологиялық карта, спутниктік бейнелер, биіктіктің сандық моделі, ординация.

\section{С.В. Солодянкина, Ю.В. Вантеева}

\section{Геосистемы Приморского хребта (Байкальский регион) Классификация и картирование}

\begin{abstract}
В статье обсуждено применение ландшафтного подхода для классификации и картирования геосистем на примере ландшафтов Приморского хребта (Байкальский регион). Для моделирования ландшафтной структуры района исследования использованы концепция геосистемы, сформулированная В. Сочавой, и метод факторально-динамических рядов фаций, разработанный А. Крауклисом. Основой для разработки иерархической классификации геосистем послужили данные полевых работ на 70-ти участках. Ординация графиков по трем параметрам (индекс топографической влажности, крутизна склона и толщина гумуса) проводилась методом тернарных графиков для группирования геосистем по классам и определения их динамического состояния. Ландшафтная карта была составлена в локальном масштабе (1:50 000) на основе данных полевых работ, DEM и дистанционного зондирования. В результате в районе исследования было выявлено 14 групп фаций. Они представлены как климаксовыми и сукцессионными стадиями, так и антропогенными модификациями. Основные классы фаций, образующиеся под воздействием локальных факторов окружающей среды, выявлены с помощью факторнодинамического анализа. Представлены они следующими динамическими рядами: сублитоморфными, субгидроморфными и субксеролитоморфными. 66 \% площади исследования занимают ландшафты сублитоморфного ряда.
\end{abstract}

Ключевые слова: факторально-динамический ряд фаций, ландшафтный подход, структура геосистемы, иерархическая классификация, ландшафтная типологическая карта, спутниковые изображения, цифровая модель рельефа, ординация.

\section{References}

1 Kolbovskii, E.Yu. (2018). GIS-modelirovanie i problemy teorii landshafta [GIS-modeling and problems of landscape theory]. Proceedings from: Modern landscape-ecological state and problems of optimization of the natural environment of the regions: XIII Mezhdunarodnaia landshaftnaia konferentsiia - XIII International Landscape Conference: In 2 vols. (Vol. 1, p. 31-34) [in Russian].

2 Sochava, V.B. (1978). Vvedenie v uchenie o geosistemakh [Introduction to the theory of geosystems]. Novosibirsk: Nauka [in Russian].

3 Bastian, O., Grunewald, K., \& Syrbe, R.-U., et al. (2014). Landscape services: The concept and its practical relevance. Landscape Ecology, 29 (9), 1463-1479. 
4 Bastian, O., Grunewald, K., \& Khoroshev, A.V. (2015). The significance of geosystem and landscape concepts for the assessment of ecosystem services: Exemplified in a case study in Russia. Landscape Ecology, 30 (7), 1145-1164.

5 Semenov, Yu.M. (2014). Landscape-Geographical Support of the Ecological Policy of Nature Management in Regions of Siberia. Geography and natural Resources, 35 (3), 208-212.

6 Khoroshev, A., \& Dyakonov, K. (Eds.) (2020). Landscape Patterns in a Range of Spatio-Temporal Scales. Landscape Series, 26; 446.

7 Chernykh, D.V., \& Zolotov, D.V. (2011). Prostranstvennaia organizatsiia landshaftov basseina reki Barnaulki [Spatial organization of landscapes in the Barnaulka river basin]. Novosibirsk: Izdatelstvo SO RAN [in Russian].

8 Cherkashin, A.K. (2020). Polygeosystem Fundamentals of Landscape Science Landscape Patterns in a Range of SpatioTemporal Scales. Landscape Series, 26; 19-40.

9 Konovalova, T.I., Bessolicyna, E.P., Vladimirov, I.N., \& Istomina, E.A. et al. (2005). Landshaftno-interpretatsionnoe kartografirovanie [Landscape interpretation mapping]. Novosibirsk: Nauka [in Russian].

10 Istomina, E.A., Solodiankina, S.V., Vanteeva, Yu.V., Konovalova, T.I., Bibaeva, A.Yu., Frolov, A.A., \& Cygankova, M.V. (2018). Itogi landshaftno-kartograficheskikh issledovanii v Pribaikale [Results of landscape-cartographic research in the Baikal region]. Geodeziia i kartografiia - Geodesy and cartography, 79(2), 36-47 [in Russian].

11 Glazii, G.I. (Ed.) (1993). Atlas Baikala [Atlas of Baikal]. Moscow: Izdatelstvo Federalnoi sluzhby geodezii i kartografii Rossii [in Russian].

12 Trofimova, I.E. (2002). Tipizatsiia i kartografirovanie klimatov Baikalskoi gorno-kotlovinnoi sistemy [Typification and mapping of climates Baikal mountain Basin systems]. Geografiia i prirodnye resursy — Geography and Natural Resources, 2; 53-61 [in Russian].

13 Vanteeva, Yu.V., Rasputina, E.A., \& Solodyankina, S.V. (2019). Geoinformatsionnoe kartografirovanie landshaftov na primere Primorskogo khrebta (Pribaikale) [Geoinformation mapping of landscapes on the example of the Primorskiy Ridge (Baikal region)]. Geodeziia i kartografiia - Geodesy and Cartography, 80 (12); 20-30 [in Russian].

14 Vanteeva, J.V., \& Solodyankina, S.V. (2019). Application of geosystem approach for landscape function assessment at the local level. Proceedings of International Scientific Symposium "New trends in geography”. Skopje: Macedonian Geographical Society, 15-25.

15 Miheev, V.S., \& Rjashin, V.A. (1977). Landshafty yuga Vostochnoi Sibiri [Map Landscapes of the South of Eastern Siberia]. 1:1 500000 [in Russian].

16 Krauklis, A.A. (1979). Problemy eksperimentalnogo landshaftovedeniia [Experimental Landscape Science issues]. Novosibirsk: Nauka [in Russian].

17 Solodyankina, S.V., Vanteeva, Yu.V., Cherkashina, A.A., \& Chepinoga, V.V. (2018). Classification and mapping of topogeosystems by the method of factorial-dynamical series of facies. Geography and Natural Resources, 39 (3), 261-269.

18 Vanteeva, Y.V., \& Solodyankina, S.V. (2020). Structure and Phytomass Production of Coastal Geosystems Near Lake Baikal. Landscape Patterns in a Range of Spatio-Temporal Scales. Landscape Series, 26, 121-137.

19 Zolotov, D.V., \& Chernykh, D.V. (2017). Fatsialnaia organizatsiia vysokogorii severnogo makrosklona khrebta Kholzun (Russkii Altai) [Facial organization of the high mountains of the northern macroslope of the Kholzun ridge (Russian Altai)]. Geografiia i prirodnye resursy - Geography and Natural Resources, 4, 83-93 [in Russian].

20 Prokaev, V.I. (1983). Tipy fatsii - edinitsy detalnogo landshaftnogo kartografirovaniia [Facies types — units of detailed landscape mapping]. Izvestiia VGO - VGO News, 115(6), 432-441 [in Russian].

21 Sochava, V.B. (1986). Problemy fizicheskoi geografii i geobotaniki [Issues of physical geography and geobotany]. Novosibirsk: Nauka [in Russian]. 